\title{
BIOMASS AND CHEMICAL RESPONSES OF Desmanthus spp. ACCESSIONS SUBMITTED TO WATER DEPRIVATION ${ }^{1}$
}

\author{
ILDJA VIVIANE DE QUEIROZ ${ }^{2}$, MÉRCIA VIRGINIA FERREIRA DOS SANTOS ${ }^{2}$, JAMES PIERRE MUIR $^{3}$, JOSÉ \\ CARLOS BATISTA DUBEUX JUNIOR ${ }^{4}$, MÁRCIO VIEIRA DA CUNHA ${ }^{*}$, ALEXANDRE CARNEIRO LEÃO DE \\ MELLO $^{2}$
}

\begin{abstract}
Due to the predictions of climate change, there is a need to identify forage plants that can keep their productivity and nutritive value under hydric stress. The objective of this study was to evaluate the biomass and chemical responses of three Desmanthus spp. accessions under two water deprivation regimens ( 7 and 21-day). The experimental design used was randomized blocks in a $3 \times 2$ factorial arrangement (access and water deprivation) with four replications. There were reductions in the biomasses of leaf and stem fractions of $64 \%$ and $51 \%$, respectively. The $43 \mathrm{~F}$ accession showed greater leaf (1.86 g.plant $\left.{ }^{-1}\right)$ and stem (1.97 g.plant $\left.{ }^{-1}\right)$ biomasses under a total water restriction of 21 days, compared to the $89 \mathrm{~F}$ and AusT accessions. In accessions $43 \mathrm{~F}$ and $89 \mathrm{~F}$, there were carbohydrate accumulations in the leaves of $28 \%$ and $51 \%$, respectively, under the 21 day water restriction, while AusT decreased 38\% within a 7-day interval. Water deprivation affected the chemical characteristics of the accessions. Free proline was similar among accessions and accumulated $463 \%$ more in the leaves of plants submitted to 21 -day water deprivation $\left(90.22 \mathrm{mg} \cdot \mathrm{kg}^{-1}\right)$ compared to those subjected to water deprivation for 7 days $\left(16.03 \mathrm{mg} \cdot \mathrm{kg}^{-1}\right)$. Proline and total soluble carbohydrate accumulation in $43 \mathrm{~F}$ and $89 \mathrm{~F}$ were insufficient to regulate crude protein, $\mathrm{C}$ content, and $\mathrm{C}: \mathrm{N}$ ratios. These results demonstrate the variability in drought tolerance among accessions. Accessions $43 \mathrm{~F}$ and $89 \mathrm{~F}$ were more susceptible to 21 -day water deprivation, while AusT showed greater drought tolerance.
\end{abstract}

Keywords: Forage plant. Native legume. Protein.

\section{RESPOSTAS NA BIOMASSA E QUÍMICAS DE ACESSOS DE Desmanthus spp. SUBMETIDOS A PRIVAÇÃO DE ÁGUA}

\begin{abstract}
RESUMO - Devido às previsões de mudanças climáticas, é necessário identificar plantas forrageiras que sob estresse hídrico possam manter a produtividade e o valor nutritivo. O objetivo foi avaliar a biomassa e as respostas químicas de três acessos de Desmanthus spp. em dois regimes de privação de água (7 e 21 dias). O delineamento experimental foi em blocos ao acaso em esquema fatorial 3 × 2 (acesso e privação de água), com quatro repetições. Houve redução da biomassa de folha e caule de $64 \%$ e $51 \%$, respectivamente. O $43 \mathrm{~F}$ apresentou maior biomassa de folha $\left(1,86\right.$ g.planta $\left.^{-1}\right)$ e caule $\left(1,97\right.$ g.planta $\left.{ }^{-1}\right)$ que os acessos $89 \mathrm{~F}$ e AusT, na privação de água de 21 dias. Nas folhas dos acessos $43 \mathrm{~F}$ e $89 \mathrm{~F}$, os carboidratos acumularam em torno de $28 \% \mathrm{e}$ $51 \%$, respectivamente, sob privação de 21 dias, enquanto o AusT diminuiu 38\% no intervalo de 7 dias. A privação de água afetou as características químicas dos acessos. A prolina livre foi semelhante entre os acessos e acumulou $463 \%$ a mais nas folhas de plantas com 21 dias de privação de água $\left(90,22 \mathrm{mg} \cdot \mathrm{kg}^{-1}\right)$ em relação às submetidas a 7 dias $\left(16,03 \mathrm{mg} \cdot \mathrm{kg}^{-1}\right)$. O acúmulo de prolina e carboidratos solúveis totais em $43 \mathrm{~F}$ e $89 \mathrm{~F}$ foram insuficientes para regular a proteína bruta, o teor de $\mathrm{C}$ e a relação C:N. Há variabilidade na tolerância à seca entre espécies e acessos. Os acessos 43F e 89F foram mais suscetíveis à privação de água por 21 dias, enquanto AusT mostrou maior tolerância à seca.
\end{abstract}

Palavras-chave: Planta forrageira. Leguminosa nativa. Proteína.

\footnotetext{
*Corresponding author

${ }^{1}$ Received for publication in 10/01/2020; accepted in 06/29/2021.

Paper extracted from the doctoral thesis of the first author.

${ }^{2}$ Department of Animal Science, Universidade Federal Rural de Pernambuco, Recife, PE, Brazil; ildjaviviane1@gmail.com - ORCID: 0000 -0003-3474-0018, mercia.vfsantos@ufrpe.br - ORCID: 0000-0002-7374-0910, marcio.cunha@ufrpe.br - ORCID: 0000-0002-1316-3218, alexandre.lmello@ufrpe.br - ORCID: 0000-0002-4721-9021.

${ }^{3}$ Texas A\&M AgriLife Research, Stephenville, TX, United States of America; j-muir@tamu.edu - ORCID: 0000-0003-1775-8072.

${ }^{4}$ North Florida Research \& Education Center, University of Florida, Marianna, FL, United States of America; dubeux@ufl.edu - ORCID: 0000-0001-8269-9959.
} 


\section{INTRODUCTION}

In northeastern Brazil, drought compromises the food security of several families. According to the predictions of climatic changes, droughts will become more intense and frequent. The identification of native forage plants that keep better productive performances and nutritional values under hydric stress can be a strategy to mitigate drought effects and improve the supply of feed to the animals, thus generating income and food security.

Plant water stress may be the result of a single factor or a combination of environmental conditions, root conditions, and plant genetic traits (KATSOULAS et al., 2016). Effects will depend on the intensity and duration of the water deficit or restriction (QUINTELA et al., 2015), as well as the genetic potentialities of the species to respond to the environmental stresses.

Schultze-Kraft et al. (2018) reported that legumes have the potential to contribute significantly to the sustainable intensification of livestock production in the tropics, along with the provision of ecosystem services. Native legumes from tropical America are ecologically adapted, and their wide biodiversity represents an important resource, as well as vegetal material for diverse uses in different agricultural systems (SANTOS et al., 2019). The Desmanthus genus consists of 24 leguminous species distributed in tropical and subtropical regions of America (MUIR et al., 2014). This legume is used mainly as forage (MUIR et al., 2019). These have been the subject of several studies, including native species present in Brazil's northeastern semi-arid region, where irregular rainfall patterns influence the vegetation. In this region, Desmanthus plants are commonly named 'Jureminha' (CALADO et al., 2016). Desmanthus plants can display greater herbaceous yields, help recover degraded areas, improve soil fertility and organic matter quality, and reduce industrial inputs in agriculture, thus contributing to reduction of greenhouse gas emissions (GHG). According to DIAS et al. (2019), Desmanthus plants have greater nodulation specificity and some native accessions were able to grow at a temperature of $40{ }^{\circ} \mathrm{C}$ as well as having great seed production (RANGEL; GARDINER; BURT, 2015).

The identification of genotypes with adaptive responses to water deficit is essential for forage legume breeding programs and the sustainability of regions with water scarcity. This study hypothesizes is that the accessions of Desmanthus spp. from different sites can respond differently to water deprivation in terms of biomass production and chemical composition, leading to the possibility of selecting genotypes more tolerant to the water deficit. Thus, the objective of this study was to evaluate biomass and chemical responses (nutritive value and proline) of three Desmanthus spp. accessions under two water deprivation regimens.

\section{MATERIALS AND METHODS}

The experiment was conducted in a greenhouse, from November 2014 to June 2015. Coordinates are $8^{\circ} 01^{\prime} \mathrm{S}, 34^{\circ} 57^{\prime} \mathrm{W}$, temperature ranged between 21.0 and $38.2{ }^{\circ} \mathrm{C}$, and atmospheric humidity ranged from 42 to $95 \%$ inside the greenhouse. Seedlings of three Desmanthus spp. accessions obtained from the UFRPE germplasm bank (ex-situ) in Serra Talhada were used (Table 1). Desmanthus pernambucanus (L.) Thellung accessions $43 \mathrm{~F}$ and $89 \mathrm{~F}$ were collected in the municipality of Bom Jardim, Pernambuco, on red Argisol and Vertisol, respectively (classified by Instituto Agronômico de Pernambuco, IPA, Fomento Internacional do Brasil LTDA, FIB, n⿳02/2012). Accession AusT was provided by Embrapa Tabuleiros Costeiros and was obtained from Australia. Its identification appears only as Desmanthus spp., according to the Commonwealth Scientific and Industrial Research Organization (CSIRO).

Table 1. Identification and origin of Desmanthus spp. accessions evaluated.

\begin{tabular}{cccc}
\hline Identification & Origin & Latitude $(\mathrm{S})$ & Longitude \\
\hline $43 \mathrm{~F}$ & Bom Jardim - Brazil & $7^{\circ} 47^{\prime}$ & $35^{\circ} 32^{\prime}$ \\
$89 \mathrm{~F}$ & Bom Jardim - Brazil & $7^{\circ} 50^{\prime}$ & $35^{\circ} 41^{\prime}$ \\
AusT & Ethiopia - CSIRO & $17^{\circ} 08^{\prime}$ & $-61^{\circ} 48^{\prime}$ \\
\hline
\end{tabular}

Seeds were scarified in the region opposite to the hilum and soaked in water for 24 hours. Approximately five seeds were planted in pots containing $8 \mathrm{~kg}$ of soil and $100 \mathrm{~g}$ of gravel. Buckets had a capacity of $10 \mathrm{~L}$, a height of $0.40 \mathrm{~m}$, and a diameter of $0.20 \mathrm{~m}$, and holes were drilled at the base to monitor the drained water.

The soil used as the growing medium came from a Red Dystrophic Argisoil, with little salt or sodium, which was collected at the Instituto Agronômico de Pernambuco (IPA) in Arcoverde, Pernambuco, to a $20-\mathrm{cm}$ depth. Soil fertility analysis was carried out at IPA-Recife and presented the following results: $\mathrm{pH}(\mathrm{H} 2 \mathrm{O})$ of 5.9 and $16 \mathrm{mg} \mathrm{dm}^{-3}$ of $\mathrm{P}$, as well as $2.60,0.90,0.06,0.35,1.89,3.90$ and 5.80 cmolc. $\mathrm{dm}^{-3}$ of $\mathrm{Ca}, \mathrm{Mg}, \mathrm{Na}, \mathrm{K}, \mathrm{H}$, and $\mathrm{S}$, 
respectively. The base saturation was $67 \%$, and aluminum saturation was $0 \%$. It was indicated that an application of $0.456 \mathrm{~g}$ of $\mathrm{KCl}$ and $0.198 \mathrm{~g}$ of $\mathrm{P}_{2} \mathrm{O}_{5}$ as simple superphosphate was needed for legume nutrition.

After sowing, plants received water on alternate days for 60 days, and at this time, seedlings were thinned to two plants per bucket and cut at a $15 \mathrm{~cm}$ height from the soil to have all plants uniformly re-growing. Plants of each accession were submitted to water deprivation treatments of 7 or 21 days for 252 days. Pots had a side opening of $2 \mathrm{~cm}$ at the base where the captured water and leached nutrients were received. The leachates were watered back into the originating pots in the late afternoon on the same day.

On day 147, after the uniform cutting, plant leaves were collected between 9:00 and 10:00 a.m. and analyzed for free proline content. The extraction and quantification of free proline were performed on fresh mature leaves that were fully expanded, following the proposed methodology described by Bates, Waldren and Teare (1973) and modified by Bezerra Neto and Barreto (2011).

At the end of 252 days following uniform cutting, destructive analyses were performed. Leaves, stems, and roots were collected and weighed. Roots were washed with running water for soil removal and placed for 5 minutes on paper to remove excess humidity. The material was packaged in paper bags and dried in a forced-air oven at $55^{\circ} \mathrm{C}$ until constant weight to determine the dry matter (DM). These materials were then ground in a Wiley Mill equipped with a 1-mm mesh, then in a ball-type mill, after which they were stored in plastic bags. Dry matter (DM), ash, and total soluble carbohydrate (TSC), as well as $\mathrm{N}$ and $\mathrm{C}$ contents were determined from ground material.

Leaf, stem and root DM, and ash contents were determined as described by AOAC (2019), while TSC was determined as described by Yemm and Wills (1954) and modified by Bezerra Neto and Barreto (2011)

For nitrogen and carbon determination, samples were combusted in a $\mathrm{C}$ and $\mathrm{N}$ analyzer (Elemental Americas, Inc., Mt. Laurel, NJ, USA). Crude protein content was calculated by multiplying $\mathrm{N}$ by 6.25 .

The experimental design consisted of randomized blocks in a $3 \times 2$ factorial arrangement (access and water deprivation), with four replications (pots) and an experimental unit was a single pot containing two plants. Analyses of variance (ANOVA) were performed and multiple comparisons of means, when appropriate, were made using the Tukey test for accessions and an F-test for water deprivation regimens using SAS 9.0 software. The $\mathrm{p} \leq 0.05$ value was considered significant.

\section{RESULTS AND DISCUSSION}

An accession and water deprivation interaction occurred for leaf and stem biomasses of Desmanthus spp. accessions (Table 2). The leaf and stem biomasses of the accessions of Desmanthus spp. were reduced $(\mathrm{p} \leq 0.05)$ because of the water deprivation. There were reductions in biomass for the leaf and stem fractions of $64 \%$ and $51 \%$, respectively. The $43 \mathrm{~F}$ accession showed superior $(\mathrm{p} \leq 0.05)$ leaf $\left(1.86 \mathrm{~g}\right.$ DM.plant $\left.{ }^{-1}\right)$ and stem (1.97 g DM.plant ${ }^{-1}$ ) biomasses compared to the $89 \mathrm{~F}$ and AusT accessions under water deprivation for 21 days.

Table 2. Leaf and stem biomass of Desmanthus spp. accessions subjected to 7- or 21-day water deprivation.

\begin{tabular}{|c|c|c|c|c|}
\hline \multirow{3}{*}{ Accessions } & \multicolumn{2}{|c|}{ Leaf (g DM.plant $\left.{ }^{-1}\right)$} & \multicolumn{2}{|c|}{ Stem (g DM.plant $\left.{ }^{-1}\right)$} \\
\hline & \multicolumn{2}{|c|}{ Water deprivation } & \multicolumn{2}{|c|}{ Water deprivation } \\
\hline & 7-day & 21-day & 7-day & 21-day \\
\hline $43 \mathrm{~F}$ & $3.29 \mathrm{Ba}$ & $1.86 \mathrm{Aa}$ & $4.65 \mathrm{Aa}$ & $1.97 \mathrm{Ab}$ \\
\hline $89 \mathrm{~F}$ & $3.89 \mathrm{Aa}$ & $0.82 \mathrm{Cb}$ & $3.48 \mathrm{Ba}$ & $1.20 \mathrm{Bb}$ \\
\hline AusT & $3.38 \mathrm{Ba}$ & $1.16 \mathrm{Bb}$ & $1.25 \mathrm{Ca}$ & $1.42 \mathrm{Ba}$ \\
\hline $\mathrm{CV}(\%)$ & \multicolumn{2}{|c|}{2.43} & \multicolumn{2}{|c|}{12.34} \\
\hline
\end{tabular}

Means within columns followed by different uppercase letters differ $(\mathrm{p} \leq 0.05)$ according to a Tukey multiple mean separation test. Means within lines followed by different lowercase letters differ $(p \leq 0.05)$ according to the $F$ test.

The low availability of water in the plants reduced biomass production (Table 2), probably due to low leaf water potential, transpiration, and photosynthetic rate, as well as changes in the assimilated partition between plant parts. Diniz Neto et al. (2013) observed that an increase in the water availability in the soil stimulated plant growth of Desmanthus virgatus L. Willd. at four levels of water availability and four cropping ages

In addition, an accession under water deprivation showed interaction in terms of dry matter (DM) and ash content (Table 3). Water deprivation for 21 days increased the DM of leaf fractions by $33 \%$ in Desmanthus spp. accessions compared to 7 days, with AusT presenting 52\% higher DM 
(342.38 g. $\left.\mathrm{kg}^{-1}\right)$ than the DM levels of $43 \mathrm{~F}$ (225.95 g.kg $\left.{ }^{-1}\right)$.

Knowledge about the nutrient composition of forage is essential for balanced livestock nutrition, animal health and keeping the levels of productivity (KI et al., 2017). The DM content varied widely between the accessions and period of water deprivation (Table 3), as expected (182.70 $342.38 \mathrm{~g} . \mathrm{kg}^{-1}$ for leaves and $443.32-500.36 \mathrm{~g} . \mathrm{kg}^{-1}$ for stems). The amount of ash in leaf fractions increased in $43 \mathrm{~F}$ and AusT accessions when submitted to 21 versus 7 days of water deprivation. The chemical composition of forage is related to the water supply (SILVA et al., 2017). Souza et al. (2020) observed that there is a positive relationship between the synthesis and concentrations of condensed tannin with soil fertility and air temperature, whereas an inverse relationship to the available water exists for the species and sites evaluated.

Table 3. Dry matter (DM) and ash content from Desmanthus spp. plant fractions accessions subjected to 7- or 21-day water deprivation regimens.

\begin{tabular}{|c|c|c|c|c|c|}
\hline \multirow{3}{*}{ Plant fraction } & \multirow{3}{*}{ Accessions } & \multicolumn{2}{|c|}{$\mathrm{DM}\left(\mathrm{g} \cdot \mathrm{kg}^{-1}\right)$} & \multicolumn{2}{|c|}{$\operatorname{Ash}\left(\mathrm{g} \cdot \mathrm{kg}^{-1}\right)$} \\
\hline & & \multicolumn{2}{|c|}{ water deprivation } & \multicolumn{2}{|c|}{ water deprivation } \\
\hline & & 7-day & 21-day & 7-day & 21-day \\
\hline \multirow{3}{*}{ Leaf } & $43 \mathrm{~F}$ & $182.17 \mathrm{Cb}$ & $225.96 \mathrm{Ca}$ & $89.98 \mathrm{Ab}$ & $92.30 \mathrm{Ba}$ \\
\hline & $89 \mathrm{~F}$ & $249.68 \mathrm{Ab}$ & $284.29 \mathrm{Aa}$ & $79.64 \mathrm{Ca}$ & $78.46 \mathrm{Ca}$ \\
\hline & AusT & $211.70 \mathrm{Bb}$ & $342.38 \mathrm{Ba}$ & $86.66 \mathrm{Bb}$ & $99.94 \mathrm{Aa}$ \\
\hline $\mathrm{CV}(\%)$ & & \multicolumn{2}{|c|}{3.01} & \multicolumn{2}{|c|}{0.40} \\
\hline \multirow{3}{*}{ Stem } & $43 \mathrm{~F}$ & $500.36 \mathrm{Ba}$ & $476.64 \mathrm{Bb}$ & $32.06 \mathrm{Aa}$ & $27.89 \mathrm{Aa}$ \\
\hline & $89 \mathrm{~F}$ & $483.46 \mathrm{Ca}$ & $489.15 \mathrm{Aa}$ & $34.53 \mathrm{Aa}$ & $26.37 \mathrm{Ab}$ \\
\hline & AusT & $513.41 \mathrm{Aa}$ & $443.32 \mathrm{Cb}$ & $27.39 \mathrm{Ba}$ & $29.40 \mathrm{Aa}$ \\
\hline $\mathrm{CV}(\%)$ & & \multicolumn{2}{|c|}{1.42} & \multicolumn{2}{|c|}{7.05} \\
\hline
\end{tabular}

Means within columns followed by different uppercase letters differ $(p \leq 0.05)$ according to a Tukey multiple mean separation test. Means within lines followed by different lowercase letters differ $(p \leq 0.05)$ according to the $\mathrm{F}$ test.

The amount of ash in leaf fractions increased by 2.60 and $15.32 \%$ in $43 \mathrm{~F}$ and AusT accessions, respectively, when submitted to 21 versus 7 days of water deprivation. Accession AusT had $99.94 \mathrm{~g}$ ash. $\mathrm{kg}^{-1}$, approximately 1.08 and 1.27 times greater than $43 \mathrm{~F} \quad\left(92.30 \quad\right.$ g. $\left.\mathrm{kg}^{-1}\right)$ and $89 \mathrm{~F}$ $\left(78.46 \mathrm{~g} . \mathrm{kg}^{-1}\right)$ after 21 days of deprivation. Accession $89 \mathrm{~F}$ decreased $2 \%$ in leaf ash content when submitted to 21-day water deprivation compared to 7 days, and had a decrease of $0.24 \%$ in the stem fraction, resulting in low leaf $\left(0.82 \mathrm{~g} \mathrm{DM}\right.$.plant $\left.{ }^{-1}\right)$ and stem (1.20 g DM.plant ${ }^{-1}$ ) mass accumulation (Table 2).

Crude protein $(\mathrm{CP})$ and nitrogen $(\mathrm{N})$ content (Table 4) were influenced $(p \leq 0.05)$ by the interaction between water deprivation and Desmanthus spp. accessions. Accession 43F leaves had lower CP $\left(193.42 \mathrm{~g} . \mathrm{kg}^{-1}\right)$ than $89 \mathrm{~F}$ (211.79 g. $\left.\mathrm{kg}^{-1}\right)$ and AusT (229.03 g. $\left.\mathrm{kg}^{-1}\right)$ when watered every 21 days. There was also an increase in stem CP when watered in intervals of 21 days, $9 \%$ $\left(77.46 \mathrm{~g} . \mathrm{kg}^{-1}\right)$ for $43 \mathrm{~F}, 49 \%\left(80.68 \mathrm{~g} . \mathrm{kg}^{-1}\right)$ for $89 \mathrm{~F}$, and $28 \%\left(86.54 \mathrm{~g}^{\mathrm{kg}} \mathrm{kg}^{-1}\right)$ for AusT compared to the 7day regimen.

The CP values observed are considered elevated (Table 4), notably in the leaf fraction (193.42-229.03 g DM. $\left.\mathrm{kg}^{-1}\right)$. However, high protein contents do not necessarily indicate that the protein is available to ruminants because it may be bound to fiber or condensed tannin. Secondary compounds, such as condensed tannins, reduce the benefit of protein since they precipitate in the rumen, also inhibiting animal consumption due to palatability issues (MUIR et al., 2015).

The $\mathrm{C}$ contents and $\mathrm{C}: \mathrm{N}$ (Table 5) were influenced $(p \leq 0.05)$ by an interaction of water deprivation and Desmanthus spp. accessions. Accession AusT showed the greatest leaf $\mathrm{C}$ content $\left(390.52 \mathrm{~g}^{\mathrm{kg}} \mathrm{kg}^{-1}\right)$ when subjected to the 21-day water deprivation regimen. The leaf C:N ratios of 43F (12) and $89 \mathrm{~F}$ (11) accessions increased, while they decreased in the stems in 43F (33) and 89F (31) when submitted to 21-day water deprivations.

Carbon and nitrogen contents in the AusT accession contributed to a lower C:N ratio in the leaf fractions (11) and stems (29) of the plants subjected to the 21-day water deprivation, indicating a possible greater efficiency in $\mathrm{N}$ release during the decomposition of these materials (APOLINÁRIO et al., 2014). The leaf $\mathrm{C}: \mathrm{N}$ ratios of the $43 \mathrm{~F}$ and $89 \mathrm{~F}$ accessions increased while they decreased in $43 \mathrm{~F}$ and $89 \mathrm{~F}$ stems when subjected to 21-day water deprivations. Desmanthus pernambucanus may therefore promote a release of nutrients and less energy production for microorganisms during rumen organic matter decomposition compared to AusT under 21-day water deprivation. In addition, AusT may release excess of $\mathrm{N}$ to the surrounding soil, which may eventually be available to associated plants. 
Table 4. Crude protein and nitrogen content of Desmanthus spp. accessions plant fractions subjected to 7- or 21-day water deprivation regimens.

\begin{tabular}{|c|c|c|c|c|c|}
\hline \multirow{3}{*}{ Plant fraction } & \multirow{3}{*}{ Accessions } & \multicolumn{2}{|c|}{ Protein $\left(\mathrm{g} \cdot \mathrm{kg}^{-1}\right)$} & \multicolumn{2}{|c|}{ Nitrogen $\left(\mathrm{g} \cdot \mathrm{kg}^{-1}\right)$} \\
\hline & & \multicolumn{2}{|c|}{ water deprivation } & \multicolumn{2}{|c|}{ water deprivation } \\
\hline & & 7-day & 21-day & 7-day & 21-day \\
\hline \multirow{3}{*}{ Leaf } & $43 \mathrm{~F}$ & $219.68 \mathrm{Aa}$ & $193.42 \mathrm{Cb}$ & $35.15 \mathrm{Aa}$ & $30.95 \mathrm{Cb}$ \\
\hline & $89 \mathrm{~F}$ & $225.00 \mathrm{Aa}$ & $211.79 \mathrm{Ba}$ & $36.00 \mathrm{Aa}$ & $33.89 \mathrm{Ba}$ \\
\hline & AusT & $222.56 \mathrm{Aa}$ & $229.03 \mathrm{Aa}$ & $35.61 \mathrm{Aa}$ & $36.65 \mathrm{Aa}$ \\
\hline $\mathrm{CV}(\%)$ & & \multicolumn{2}{|c|}{2.39} & \multicolumn{2}{|c|}{2.39} \\
\hline \multirow{3}{*}{ Stem } & $43 \mathrm{~F}$ & $70.85 \mathrm{Ab}$ & $77.46 \mathrm{Ba}$ & $11.34 \mathrm{Ab}$ & $12.39 \mathrm{Ba}$ \\
\hline & $89 \mathrm{~F}$ & $54.15 \mathrm{Bb}$ & $80.68 \mathrm{Ba}$ & $8.66 \mathrm{Ab}$ & $12.91 \mathrm{Ba}$ \\
\hline & AusT & $67.49 \mathrm{Ab}$ & $86.54 \mathrm{Aa}$ & $10.80 \mathrm{Ab}$ & $13.85 \mathrm{Aa}$ \\
\hline $\mathrm{CV}(\%)$ & & \multicolumn{2}{|c|}{3.21} & \multicolumn{2}{|c|}{3.21} \\
\hline
\end{tabular}

Means within columns followed by different uppercase letters differ $(p \leq 0.05)$ according to a Tukey multiple mean separation test. Means within lines followed by different lowercase letters differ $(p \leq 0.05)$ according to the F test.

Table 5. Carbon content and C:N of Desmanthus spp. accessions plant fractions submitted to 7- or 21-day water deprivation regimens.

\begin{tabular}{|c|c|c|c|c|c|}
\hline \multirow{3}{*}{ Plant fraction } & \multirow{3}{*}{ Accessions } & \multicolumn{2}{|c|}{ Carbon $\left(\mathrm{g} \cdot \mathrm{kg}^{-1}\right)$} & \multicolumn{2}{|c|}{$\mathrm{C}: \mathrm{N}$} \\
\hline & & \multicolumn{2}{|c|}{ water deprivation } & \multicolumn{2}{|c|}{ water deprivation } \\
\hline & & 7-day & 21-day & 7-day & 21-day \\
\hline \multirow{3}{*}{ Leaf } & $43 \mathrm{~F}$ & $373.71 \mathrm{Cb}$ & $378.62 \mathrm{Ca}$ & $10.66 \mathrm{Ab}$ & $12.23 \mathrm{Ab}$ \\
\hline & $89 \mathrm{~F}$ & $385.47 \mathrm{Ba}$ & $379.93 \mathrm{Bb}$ & $10.71 \mathrm{Aa}$ & $11.21 \mathrm{Ba}$ \\
\hline & AusT & $388.19 \mathrm{Ab}$ & $390.52 \mathrm{Aa}$ & $10.90 \mathrm{Aa}$ & $10.66 \mathrm{Ca}$ \\
\hline CV (\%) & & \multicolumn{2}{|c|}{0.15} & \multicolumn{2}{|c|}{2.27} \\
\hline \multirow{3}{*}{ Stem } & $43 \mathrm{~F}$ & $406.49 \mathrm{Aa}$ & $403.98 \mathrm{Aa}$ & $35.87 \mathrm{Ba}$ & $32.60 \mathrm{Aa}$ \\
\hline & $89 \mathrm{~F}$ & $402.62 \mathrm{Aa}$ & $398.91 \mathrm{Aa}$ & $46.81 \mathrm{Aa}$ & $30.90 \mathrm{Ab}$ \\
\hline & AusT & $401.18 \mathrm{Aa}$ & $398.42 \mathrm{Aa}$ & $37.15 \mathrm{Ba}$ & $28.77 \mathrm{Bb}$ \\
\hline $\mathrm{CV}(\%)$ & & \multicolumn{2}{|c|}{0.21} & \multicolumn{2}{|c|}{5.52} \\
\hline
\end{tabular}

Means within columns followed by different uppercase letters differ $(p \leq 0.05)$ according to a Tukey multiple mean separation test. Means within lines followed by different lowercase letters differ $(p \leq 0.05)$ according to the F test.

Accession AusT may have undergone fewer $\mathrm{C}$ losses due to respiration compared to $43 \mathrm{~F}$ (378.62 g. $\mathrm{kg}^{-1}$ ) and 89F (379.93 g.kg ${ }^{-1}$ ), which would result in greater amounts of $\mathrm{C}$ available in the forage.

The $\mathrm{C}$ content varied widely by accessions and period of water deprivation (373.71390.52 g. $\mathrm{kg}^{-1}$ for leaves and 398.42-406.49 g. $\mathrm{kg}^{-1}$ for stems). According to Lima et al. (2018), silvopastoral systems using tree legumes can potentially serve as greater $\mathrm{C}$ sinks than monoculture pastures of grass, as silvopastoral systems can also provide other services to farmers.

There were no interactions among accessions and water intervals for free proline in the green leaves $(p \geq 0.05)$, but there were isolated simple effects of accession and water deprivation. When subjected to water deprivation of 21 days, proline content increased in leaves $(p \leq 0.05)$. The average proline content in the leaves of the plants subjected to 7-day water deprivation was $16.03 \mathrm{mg} \cdot \mathrm{kg}^{-1}$, while in the plants under 21 days of water restriction was 90.22 mg. $\mathrm{kg}^{-1}$; the latter showed a $463 \%$ greater content than the first one. Proline content in fresh leaves was greater in 43F (89.46 mg. $\left.\mathrm{kg}^{-1}\right)$ compared to $89 \mathrm{~F}$ (45.91 mg.kg ${ }^{-1}$ ) and AusT (45.01 mg. $\mathrm{kg}^{-1}$ ).

The average proline content in the leaves of the plants under 21 days of water deprivation was greater than that of plants under the 7-day deprivation treatment. Similar proline accumulation in plants under water stress was also observed by Pereira et al. (2012), with five genotypes of Arachis hypogaea L. subjected to moderate water stress for 7 days in a greenhouse trial. The free proline concentrations increased in all plants under stress conditions and were $105 \%$ greater in a droughtresistant cultivar compared to the others.

According to Borgo, Marur and Vieira (2015), proline accumulates in many plant species in response to abiotic stresses, such as drought and salinity. Thus, the proline increases observed in the plants submitted to 21 days of water deprivation demonstrate a response to stress caused by the dehydration of the plant tissues. Proline accumulation functions as a cellular osmotic adjustment, which, according to Verslues and Sharma (2010), may act as a "water substitute" that 
stabilizes the cell structures via hydrophilic interactions and hydrogen bonds. Verbruggen and Hermans (2008) suggested that proline acts on membranes and protects proteins against the effects of elevated concentrations of inorganic ions and extreme temperatures, stabilizing cell structures and detoxifying free radicals. However, according to Monteiro et al. (2014), such protection is effective only during short periods.

The proline contents in fresh leaves were greater in $43 \mathrm{~F}$ compared to $89 \mathrm{~F}$ and AusT. The greater accumulation of proline in $43 \mathrm{~F}$ may explain the lower DM content and greater production of this accession. However, it was insufficient to be used as an energy source for redistributing $\mathrm{N}$ and $\mathrm{C}$ during the recovery of physiological activities of the plants, as reported by Szabados and Savouré (2010).

An interaction effect between accessions and water deprivation $(\mathrm{p} \leq 0.05)$ was observed for the total soluble carbohydrates (TSC) content (Table 6), with greater content in Desmanthus spp. leaves subjected to water deprivation. However, $43 \mathrm{~F}$ and $89 \mathrm{~F}$ showed the greatest TSC contents, 32.62 and 33.07 g. $\mathrm{kg}^{-1}$, respectively, under 21-day water deprivation, which represented a 28 and $51 \%$ increase, respectively, compared to 7 -day water deprivation.

Table 6. Total soluble carbohydrates $\left(\mathrm{g} \cdot \mathrm{kg}^{-1}\right)$ in plant fractions of Desmanthus spp. accessions subjected to 7- or 21-day water deprivation regimens.

\begin{tabular}{|c|c|c|c|c|c|c|}
\hline \multirow{3}{*}{ Accessions } & \multicolumn{2}{|c|}{ Leaf } & \multicolumn{2}{|c|}{ Stem } & \multicolumn{2}{|c|}{ Root } \\
\hline & \multicolumn{2}{|c|}{ water deprivation } & \multicolumn{2}{|c|}{ water deprivation } & \multicolumn{2}{|c|}{ water deprivation } \\
\hline & 7-day & 21-day & 7 -day & 21-day & 7-day & 21-day \\
\hline $43 \mathrm{~F}$ & $25.42 \mathrm{Ab}$ & $32.62 \mathrm{Aa}$ & $12.27 \mathrm{Aa}$ & $13.39 \mathrm{Aa}$ & $11.21 \mathrm{Ca}$ & $10.00 \mathrm{Cb}$ \\
\hline $89 \mathrm{~F}$ & $21.90 \mathrm{Bb}$ & $33.07 \mathrm{Aa}$ & $9.74 \mathrm{Bb}$ & $12.25 \mathrm{Ba}$ & $13.80 \mathrm{Aa}$ & $10.75 \mathrm{Bb}$ \\
\hline AusT & $22.10 \mathrm{Ba}$ & $13.64 \mathrm{Bb}$ & $13.31 \mathrm{Aa}$ & $11.99 \mathrm{Ba}$ & $13.29 \mathrm{Ba}$ & $12.51 \mathrm{Ab}$ \\
\hline $\mathrm{CV}(\%)$ & \multicolumn{2}{|c|}{1.27} & \multicolumn{2}{|c|}{5.61} & \multicolumn{2}{|c|}{1.45} \\
\hline
\end{tabular}

Means within columns followed by different uppercase letters differ $(p \leq 0.05)$ according to a Tukey multiple mean separation test. Means within lines followed by different lowercase letters differ $(p \leq 0.05)$ according to the $\mathrm{F}$ test.

Accession $89 \mathrm{~F}$ had a $26 \%$ TSC increase in the stems when subjected to 21-day water deprivation compared to the 7-day treatment. Accessions 43F and AusT maintained TSC contents of 13.39 and 11.99 g. $\mathrm{kg}^{-1}$, respectively, during 21 and 7-day treatments. Accession 43F had the greatest stem TSC content among the accessions under 21-day water deprivation $(p \leq 0.05)$. Reductions in the TSC contents of the root fractions were observed for all accessions when subjected to 21-day water deprivation compared to 7-day treatments.

The accessions $43 \mathrm{~F}$ and $89 \mathrm{~F}$ showed greater TSC contents after 21-day water deprivation compared to 7-day water deprivation (Table 6). Such an increase could be related to the maintenance of the leaf water levels and the induced osmotic adjustments in these plants. AusT showed lower TSC content, $13.64 \mathrm{~g} . \mathrm{kg}^{-1}$, after 21-day water deprivation, a $38 \%$ reduction compared to the 7 -day water deprivation.

The superior leaf TSC content of $43 \mathrm{~F}$ and $89 \mathrm{~F}$ and lower content in the roots may be related to the tolerance strategies of these plants to low soil moisture. The TSCs are translocated from the roots to mitigate stress and acting as osmotic regulators while maintaining the water levels in the leaves as well as the osmotic balance of cells (CASTRO et al., 2007). Drought stress in soybean (Glycine max (L.) Merr.) increased the concentrations of free amino acids, proline, and soluble sugar by $42.28,65.97$, and
$13.04 \%$, respectively, in comparison with the control treatment (DU et al., 2020), contributing to the osmotic adjustment of plants.

Despite the greater nutrient absorption (99.94 g ash. $\mathrm{kg}^{-1}$, Table 3 ) and C content (Table 5), AusT had low biomass accumulation (1.16 g DM.plant ${ }^{-1}$; Table 2). However, 43F had lower ash content $\left(92.30 \mathrm{~g} . \mathrm{kg}^{-1}\right)$ compared to AusT under 21-days water deprivation, indicating less nutrient absorption and $\mathrm{CO}_{2}$ uptake (Table 5). This accession had greater mass production, $1.86 \mathrm{~g} \mathrm{DM.plant}{ }^{-1}$ (Table 2), which could be associated with the amount of proline in these plants. Proline may have shown a larger proportion of the total $\mathrm{DM}$ in $43 \mathrm{~F}$, leading to lower DM and superior biomass.

Accession AusT, despite the lower leaf TSC content, had superior CP (Table 4), C content, and $\mathrm{C}: \mathrm{N}$ ratio (Table 5). Differences in quantitative variables between 7 and 21-day water deprivations in AusT were lower than observed in the other accessions, allowing it to elongate leaves under an extended period of water deprivation. Despite the lower biomass production in AusT when comparing to $43 \mathrm{~F}$ and $89 \mathrm{~F}$, the quantitative and qualitative responses combined indicate that under extended water deprivation it may result in a superior performance in the field when compared to the other accessions. 


\section{CONCLUSION}

There was variability in drought tolerance among accessions of Desmanthus spp. Accessions $43 \mathrm{~F}$ and $89 \mathrm{~F}$ were more susceptible to water deprivation for 21 days, while AusT showed greater tolerance to drought. Considering a climate change scenario with more intense and frequent droughtS, the identification of genotypes that are more tolerant to water deficit is essential for the sustainability of regions with water scarcity.

\section{ACKNOWLEDGEMENTS}

We thank the Conselho Nacional de Desenvolvimento Científico e Tecnológico (CNPq) for the financial support and productivity scholarship to the author Mércia Virginia Ferreira dos Santos, Fundação de Amparo à Ciência e Tecnologia do Estado de Pernambuco (FACEPE), for the scholarship to the author Ildja Viviane de Queiroz. This study was financed in part by the Coordenação de Aperfeiçoamento de Pessoal de Nível Superior, Brasil (CAPES), Finance Code 001.

\section{REFERENCES}

AOAC - Association of official analytical chemists. Official methods of analysis. 21th ed. Gaithersburg: AOAC, 2019. 3290 p.

APOLINÁRIO, V. X. O. et al. Litter decomposition of signalgrass grazed with different stocking rates and nitrogen fertilizer levels. Agronomy Journal, 106: 1-6, 2014.

BATES, L. S.; WALDREN, R. P.; TEARE, I. D. Rapid determination of free proline for water-stress studies. Plant and soil, 39: 205-207, 1973.

BORGO L.; MARUR, C. J.; VIEIRA, L. G. E. Effects of high proline accumulation on chloroplast and mitoTSCndrial ultrastructure and on osmotic adjustment in tobacco plants. Acta Scientiarum. Agronomy 37: 191-199, 2015.

BEZERRA NETO E.; BARRETO L. P. Análises químicas e bioquímicas em plantas. 1. ed. Recife, PE: UFRPE, 2011. 263 p.

CALADO, T. B. et al. Morphology and productivity of "Jureminha" genotypes (Desmanthus spp.) under different cutting intensities. Revista Caatinga, 29: 742-752, 2016.

CASTRO, D. S. et al. Concentração de prolina e carboidratos solúveis totais de folhas teça (Tectona grandis L.) submetida ao estresse hídrico. Revista Brasileira de Biociências, 5: 921-923, 2007.

DINIZ NETO, M. A. et al. Disponibilidade hídrica de dois solos e diferentes idades de corte no comportamento agronômico da Jureminha. Revista Ciência Agronômica, 44: 24-33, 2013.

DIAS, S. D. et al. Morphophysiology of rhizobia isolated from native forage of fabaceae of the Caatinga. Revista Caatinga, 32: 904-14, 2019.

DU, Y. et al. Effect of drought stress at reproductive stages on growth and nitrogen metabolism in soybean. Agronomy, 10: 1-21, 2020.

KATSOULAS, N. et al. Crop reflectance monitoring as a tool for water stress detection in greenhouses: A review. Biosystems Engineering, 151: 374-398, 2016.

KI, K. S. et al. Evaluation of the nutritional value of locally produced forage in Korea using chemical analysis and in vitro ruminal fermentation. AsianAustralasian Journal of Animal Sciences, 355: 355 $-362,2017$.

LIMA, H. N. B. et al. Soil attributes of a silvopastoral system in Pernambuco Forest Zone Atributos del suelo en un sistema silvopastoril en la "Zona da Mata", Pernambuco, Brasil. Tropical Grsslands - Forrajes Tropicales, 6: 15-25, 2018.

MONTEIRO, J. G. et al. Crescimento e conteúdo de prolina em plântulas de guandu submetidas a estresse osmótico e à putrescina exógena. Pesquisa Agropecuária Brasileira, 49: 18-25, 2014.

MUIR, J. P. et al. Challenges to domesticating native forage legumes. Tropical Grassland - Forrajes Tropicales, 2: 94-96, 2014.

MUIR, J. P. et al. Sustainable intensification of cultivated pastures using multiple herbivore species. African Journal of Range \& Forage Science, 32: 97-112, 2015

MUIR, J. P. et al. Value of endemic legumes for livestock production on Caatinga rangelands. Revista Brasileira de Ciências Agrárias, 14: e5648, 2019.

PEREIRA, J. W. L. et al. Mudanças bioquímicas em genótipos de amendoim submetidos a déficit hídrico moderado. Revista Ciência Agronômica, 43: 766$773,2012$.

QUINTELA, M. P. et al. Intensity and duration of water deficit on the pathosystem sugarcane $\mathrm{x}$ Meloidogyne incognita. Revista Brasileira de 
Engenharia Agrícola e Ambiental, 19: 581-586, 2015.

RANGEL, J. H. A.; GARDINER, C. P.; BURT, R. L. Dormancy releasing mechanisms in soil seed banks of Desmanthus genotypes. Revista Caatinga, 28: $90-99,2015$.

SANTOS, M. V. F. et al. Native shrub-tree legumes of tropical America with potential for domestication. The Journal of the International Legume Society, 17:33-35, 2019.

SCHULTZE-KRAFT, R. et al. Tropical forage legumes for environmental benefits: An overview. Tropical Grsslands - Forrajes Tropicales, 6: 1-14, 2018.

SILVA, S. F. et al. Agronomic characteristics and chemical composition of Gliricidia sepium grown under different residual heights in different seasons. Ciencia Investigación Agraria, 44: 35-42, 2017.

SOUZA, R. T. A. et al. Association of edaphoclimatic characteristics and variability of condensed tannin content in species from Caatinga. Revista Ciência Agronômica, 51: e20196611, 2020.

SZABADOS, L.; SAVOURÉ, A. Proline: a multifunctional amino acid. Trends. Plant Science, 15: 89-97, 2010.

VERBRUGGEN, N.; HERMANS, C. Proline accumulation in plants: a review. Amino Acids, 35: 753-759, 2008.

VERSLUES, P. E.; SHARMA, S. Proline metabolism and its implications for plantenvironment interaction. The Arabidopsis Book, 8: e0140, 2010

YEMM, E. W.; WILLIS, A. J. The estimation of carbohydrates in plant extracts by anthrone. Biochemical journal, 57: 508-514, 1954. 